\title{
Characterization of Heat Shock Protein Expression in Apple Peel under Field and Laboratory Conditions
}

\author{
Mark A. Ritenour, ${ }^{1}$ Sunita Kochhar, and Larry E. Schrader ${ }^{2}$ \\ Tree Fruit Research and Extension Center, Washington State University, Wenatchee, WA 98801-1230 \\ Tsui-Ping Hsu and Maurice S.B. Ku \\ School of Biological Sciences, Washington State University, Pullman, WA 99164-4238
}

\begin{abstract}
AdDitional INDEX wORDS. HSP, smHSP, sunburn, sunscald, Malus domestica, Malus sylvestris var. domestica, high temperature
\end{abstract}

\begin{abstract}
Aвstract. Western immunoblot analyses showed that small heat shock proteins (smHSPs) are low or undetectable in the peel of 'Fuji', 'Jonagold', 'Criterion', 'Gala', and 'Delicious' apples [(Malus sylvestris (L.) Mill var. domestica (Borkh.) Mansf.] growing shaded within the tree canopy (shade apples), but are high in apples growing exposed to direct sunlight (sun apples). 'Fuji', 'Jonagold', and 'Gala' sun apples sampled biweekly between 1 July and 21 Oct. 1997 were highest in content of smHSPs on 31 July, 13 Aug., and 10 Sept., corresponding to some of the warmest periods of the sampling period. The smHSPs started to disappear first in 'Gala', the earliest maturing cultivar, and last in 'Fuji', the latest maturing cultivar indicating that maturity might play a role in regulating smHSP accumulation. In sun apple fruit left on trees for 60 to 120 days beyond commercial maturity and exposed to field temperatures as low as $-4^{\circ} \mathrm{C}$, a $71.7 \mathrm{ku}(\mathrm{u}$ = unified atomic mass unit) polypeptide was detected with a polyclonal antiwheat (Triticum aestivum L.) HSP70 in the peel and cortex of all five cultivars. While no smHSPs were detected in these apples, three smHSPs, as detected by antibodies against pea (Pisum sativum L.) cytosolic HSP18.1, could be induced in the same fruit 24 hours after heating to $45^{\circ} \mathrm{C}$ for 4 hours. In 'Fuji' shade apples heated at $40{ }^{\circ} \mathrm{C}$, smHSP accumulation was detected after the second hour of a 4-hour heat treatment and continued to increase over the next 48 hours at $22^{\circ} \mathrm{C}$. Levels of $\mathrm{HSP} 70$ did not change in ' $\mathrm{Fuji}$ ' shade apples heated at $45{ }^{\circ} \mathrm{C}$ for 2,4 , or 6 hours, but smHSPs became detectable immediately after each of these heat treatments and further increased over the next 24 hours at $22^{\circ} \mathrm{C}$. Accumulation of smHSPs was maximal in the 4-hour heat treatment. After a 4-hour heat treatment at $45^{\circ} \mathrm{C}$, smHSPs increased during the next 48 hours at $22{ }^{\circ} \mathrm{C}$ and then declined by 72 hours. Using two-dimensional electrophoretic analysis, as many as 17 proteins ranging from 15 to $29 \mathrm{ku}$ were found to accumulate in the peel 48 hours after a 4-hour heat treatment. Thus, apples can respond rapidly to high temperature stress, even at advanced stages of maturity, by synthesizing smHSPs, which likely play an important role in protecting cellular biochemical processes during these periods of stress.
\end{abstract}

Many organisms accumulate heat shock proteins (HSPs) in response to high nonlethal temperatures (Vierling, 1991). Several classes of HSPs exist and the composition of HSPs varies among organisms. The HSP70s are highly conserved among prokaryotes and eukaryotes and their expression is both constitutive and heatinduced (Lindquist and Craig, 1988; Vierling, 1991). The HSP70s act to prevent aggregation of unfolded proteins (Hendrick and Hartl, 1995). Gatenby and Viitanen (1994) and Hartl (1996) have described the constitutive presence of HSP70s and their role as molecular chaperones.

The small heat-shock proteins (smHSPs) are between $\approx 15$ to $30 \mathrm{ku}(\mathrm{u}=$ unified atomic mass unit) and are less conserved in nature (Waters et al., 1996) than are the HSP70s. While the predominant HSPs of many eukaryotes are the HSP70s, the smHSPs predominate in plant species during heat stress (Waters et al., 1996). Furthermore, while some HSP70s are constitutively expressed (Perdue et al., 1998), smHSPs are rarely expressed in

Received for publication 27 Dec. 2000. Accepted for publication 27 Apr. 2001. We gratefully acknowledge financial support of the Washington State Tree Fruit Research Commission. We also thank Elizabeth Vierling at the University of Arizona for generous donations of anti-HSP18.1 antibodies from pea and antiwheat HSP70 antibodies. The cost of publishing this paper was defrayed in part by the payment of page charges. Under postal regulations, this paper therefore must be hereby marked advertisement solely to indicate this fact.

${ }^{1}$ Former research associate. Current address: Indian River Research and Education Center, University of Florida, 2199 S. Rock Rd., Ft. Pierce FL 34945-3138; e-mail: mrit@gnv.ifas.ufl.edu.

${ }^{2}$ Corresponding author; e-mail: schrader@wsu.edu. nonheat-stressed vegetative tissue, but can increase 2000-fold (to over 1\% of total protein) upon heat stress (DeRocher et al., 1991; Waters et al., 1996). In vitro, several smHSPs protect cellular constituents and metabolic functions. For example, HSP18.1, a Class I cytosolic smHSP in pea (Pisum sativum), forms oligomers of 12 subunits with molecular weights between 200 to $240 \mathrm{ku}$ (Lee et al., 1995) and can bind denatured enzymes. Thus, smHSPs help by preventing aggregation and promoting refolding back to functional enzymes (Jakob et al., 1993; Lee et al., 1995; 1997). This and other evidence suggest that smHSPs play an important role in adaptation of plants to high-temperature stress, but the precise mechanism of their functioning is still unclear (Härndahl et al., 1999).

Our major goal is to understand the cause(s) of sunburn of apples (Malus sylvestris var. domestica), and to determine how fruit acclimate to survive conditions of high temperature and solar irradiation. We (L.E. Schrader and J. Zhang, unpublished data) have found that sunburn occurs in apples only when the fruit surface temperature exceeds $45^{\circ} \mathrm{C}$, and that fruit not acclimated to stressful environmental conditions are more susceptible to sunburn. For example, shaded fruit that are suddenly exposed to sunlight, by pruning or the shifting of a branch laden with fruit, will sunburn at a peel temperature 1 to $4{ }^{\circ} \mathrm{C}$ lower than will fruit that are acclimated by daily exposure to full sunlight (L.E. Schrader, unpublished data). Also, fruit are more likely to sunburn if rapidly changing weather conditions cause a sharp increase in air temperature than if air temperature increases gradu- 
ally over several days. Acclimation occurs in the field and helps protect fruit from sunburn, but the factors responsible for this induced tolerance are not known.

We hypothesized that HSPs are induced in peel of sunexposed fruit and play a role in acclimating apples to near-lethal temperatures. One objective of the present study was to characterize HSP accumulation in the peel of apples from several cultivars and maturity stages using fruit growing shaded within the tree canopy (shade apples) or exposed to direct sunlight (sun apples). A second objective was to examine induction of HSPs under controlled environments to characterize the influence of temperature and duration of heat shock (i.e., length of incubation at a given temperature) on the rise and fall of HSP70 and smHSPs. Ferguson et al. (1998) reported increased expression of HSP mRNA and radiolabeled protein in apple fruit cortex $(\geq 5 \mathrm{~mm}$ below the skin of the fruit) associated with high daily temperatures. Because sunburn occurs in the apple peel, we studied proteins in the peel (epidermal and subepidermal tissue up to $\approx 1$ $\mathrm{mm}$ from the surface) using antibodies specific to certain HSPs. Preliminary reports of our work on HSPs in apple fruit were published previously (Kochhar et al., 2000; Ritenour et al., 1998).

\section{Materials and Methods}

Sample Collection. During the 1997 growing season, 'Jonagold', 'Criterion', 'Gala', and 'Delicious' apples were harvested from 10-year-old trees trained to a slender spindle at the Washington State University Tree Fruit Research and Extension Center (TFREC), Wenatchee, Wash. 'Fuji' apples were collected from 11-year-old trees trained to a central leader and located $\approx 8$ $\mathrm{km}$ north of the TFREC. From these orchards, apples growing exposed to direct sunlight between at least $10 \mathrm{AM}$ and $2 \mathrm{PM}$ (sun) and growing shaded within the tree canopy (shade) were harvested and transported to the laboratory in plastic bags for treatments and/or HSP analysis. Fruit that were shaded in the canopy were chosen for comparison to sun fruit rather than using the shaded side of sun fruit because the back side of sun fruit was warmed by heat dissipated from the exposed side, and also intercepted some scattered and reflected irradiation. Unless otherwise stated, heat treatments and samples for HSP analysis were taken on the day of harvest. All experiments included at least three replicates (one fruit per replicate) and replicates gave similar results except where noted. For HSP analysis, $1 \mathrm{~g}$ of apple peel was excised with a peeler from the most heated area of sun apples (area receiving direct sunlight during the hottest part of the day) or from the most shaded area of shade apples. The thin tissue segments were immediately frozen using dry ice, freeze-dried, and then stored at $-34^{\circ} \mathrm{C}$ until HSPs were extracted. Apples were used from the same orchards in 1999 except that 'Fuji' apples were harvested from 3-year-old trees trained to a central leader at the TFREC.

To determine whether HSPs were still present in apples 60 to $120 \mathrm{~d}$ beyond commercial maturity and if HSPs could still be heat-induced in these apples, sun apples of the five cultivars were harvested 22 Dec. 1999 from the same trees used in 1997. Tissue samples were excised, frozen, and stored as before. Apples harvested at maturity and placed in cold storage $\left(4^{\circ} \mathrm{C}\right)$ were compared to those left in the field.

Heat treatments. 'Fuji' shade apples were heat treated in a temperature-controlled water bath to the desired temperature by placing apples inside 3.8-L, Ziploc freezer bags (DowBrands L.P., Indianapolis, Ind.) (0.069-mm-thick plastic) and submerg- ing the apples (four per bag) below water level. The bags were braced so that they remained open at the top for gas exchange. Using copper-constantan thermocouples (0.254-mm-diameter wire) inserted just beneath the peel, peel temperatures were monitored during incubation in the water bath. In a $40{ }^{\circ} \mathrm{C}$ bath, peel temperature increased from room temperature $\left(22^{\circ} \mathrm{C}\right)$ to 38 ${ }^{\circ} \mathrm{C}$ in $45 \mathrm{~s}$, and then increased asymptotically to $40^{\circ} \mathrm{C}$ during the next $20 \mathrm{~min}$. In the $45^{\circ} \mathrm{C}$ bath, peel temperature increased from room temperature to $41^{\circ} \mathrm{C}$ in $72 \mathrm{~s}$, and then increased asymptotically to $45^{\circ} \mathrm{C}$ during the next $32 \mathrm{~min}$. After heat treatments, apple peel samples for HSP analysis were either excised immediately from the heated surface and frozen, or fruit were held at room temperature $\left(22^{\circ} \mathrm{C}\right)$ for stated lengths of time before HSP tissue samples were excised. Samples were either frozen with dry ice, freeze-dried, and stored at $-34{ }^{\circ} \mathrm{C}$, or frozen and stored in liquid nitrogen.

Protein extraction. Total proteins were extracted using a modified procedure of Van Etten et al. (1979). Samples (1 g) were pulverized and transferred to test tubes containing 0.1-g polyvinylpolypyrrolidone. In rapid succession, $5 \mathrm{~mL}$ of cold (4 ${ }^{\circ} \mathrm{C}$ ) extraction buffer (250 mm Tris- $\mathrm{HCl}, \mathrm{pH} 7.5,700 \mathrm{~mm}$ sucrose, $100 \mathrm{~mm} \mathrm{KCl}, 50 \mathrm{~mm}$ EDTA, and $0.1 \%$ (v/v) $\beta$-mercaptoethanol) was added, the sample was homogenized with a Polytron (Brinkmann, Westbury, N.Y.) on high for $30 \mathrm{~s}, 5 \mathrm{~mL}$ of Trisbuffered phenol ( $\mathrm{pH}$ 7.9) was added, and the homogenates vortexed for $2 \mathrm{~min}$. After centrifuging at 5,000 $g_{\mathrm{n}}$ for $30 \mathrm{~min}$, the upper, phenol layer was removed and reextracted twice to further purify the HSPs in the phenol phase. An equal volume of extraction buffer was added, vortexed for $1 \mathrm{~min}$, and centrifuged at 5,000 $g_{\mathrm{n}}$ for $20 \mathrm{~min}$. Five volumes of cold methanol solution (containing $100 \mathrm{~mm}$ ammonium acetate and $10 \mathrm{~mm} \beta$ mercaptoethanol) were added to the phenol phase and then placed at $-4{ }^{\circ} \mathrm{C}$ overnight to precipitate protein.

Protein precipitated after phenol purification was recovered by centrifuging at $12,000 \mathrm{~g}_{\mathrm{n}}$ for $10 \mathrm{~min}$. The pellet was washed twice with $1 \mathrm{~mL}$ of the methanol solution and then twice with acetone containing $10 \mathrm{~mm} \beta$-mercaptoethanol. For SDS-PAGE, the pellet was air-dried, resuspended in SDS buffer $(25 \mathrm{~mm}$ Tris, $\mathrm{pH} 7.5,1 \%(\mathrm{w} / \mathrm{v})$ SDS, $10 \%(\mathrm{v} / \mathrm{v})$ glycerol, $5 \%(\mathrm{v} / \mathrm{v}) \beta-$ mercaptoethanol, and $0.002 \%(\mathrm{w} / \mathrm{v})$ bromphenol blue), and boiled for $2 \mathrm{~min}$. For two-dimensional electrophoretic analysis, the pellet was resuspended in a lysis buffer solution containing $8 \mathrm{M}$ urea, 4\% (v/v) nonidet P40, 0.02\% (v/v) $\beta$-mercaptoethanol, $1.6 \%(\mathrm{w} / \mathrm{v})$ ampholyte $\mathrm{pH} 5$ to 7 , and $0.4 \%(\mathrm{w} / \mathrm{v})$ ampholyte $\mathrm{pH}$ 3.5 to 10 . Sample protein concentration was determined in triplicates according to Bradford (1976) using Coomassie Blue reagent (Bio-Rad, Richmond, Calif.).

GEL ELECTROPHORESIS AND IMMUNOBLOTTING OF HSPs. For SDS-PAGE, prestained molecular weight standards (Bio-Rad) were loaded on one lane, and $35 \mu \mathrm{g}$ of protein sample was loaded onto each of the other lanes of a 7.5 to $15 \%(\mathrm{w} / \mathrm{v})$ linear acrylamide gradient slab gel. Proteins were separated using a Protean II electrophoresis apparatus (Bio-Rad) according to Laemmli (1970). For immunoblotting, proteins were transferred to a nitrocellulose membrane $(0.45 \mu \mathrm{m})$ using a Trans-Blot SD semidry apparatus (Bio-Rad) in alkaline transfer buffer containing SDS (20 mм Tris, $150 \mathrm{~mm}$ Glycine, 0.01\% (w/v) SDS, and $20 \%(\mathrm{v} / \mathrm{v})$ methanol). After transfer of proteins to the nitrocellulose membrane, the membrane was blocked with a blocking solution containing $5 \%(\mathrm{w} / \mathrm{v})$ nonfat milk in Tris-buffered saline (TBS) solution (60 mm Tris- $\mathrm{HCl}, \mathrm{pH} 7.5$, and $1.5 \mathrm{M} \mathrm{NaCl})$ for 2 $\mathrm{h}$ and then incubated with primary antibodies (in blocking solu- 


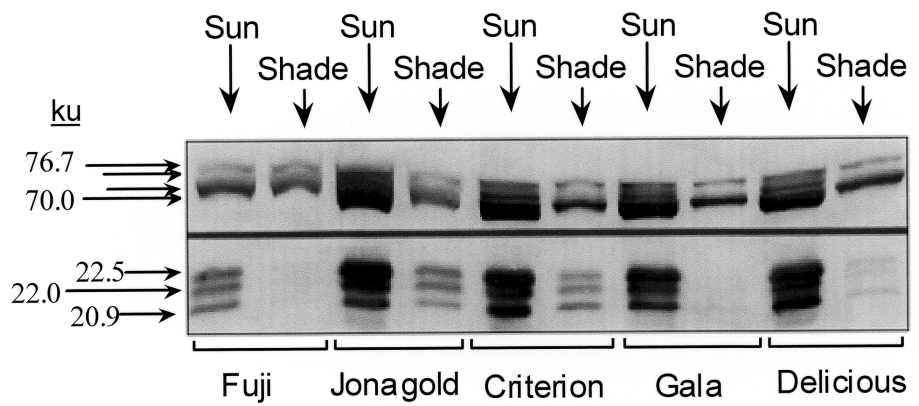

Fig. 1. Immunoblot of total protein $(35 \mu \mathrm{g} / \mathrm{lane})$ from the peel of five different apple cultivars harvested 13 Aug. 1997. Sun samples were collected from the most heated area of apples growing exposed to direct sunlight in the field. Shade samples were collected from apples growing shaded within the tree canopy. The blot was probed with antibodies against human HSP70 and pea HSP18.1. Area of the blot between the HSP70 and smHSP bands was removed to conserve space. Numbers with arrows indicate approximate molecular weights in unified atomic mass units $(\mathrm{u})$, as estimated from the molecular weight standards run with each gel.

tion) for 1 to $1.5 \mathrm{~h}$. Monoclonal antibodies raised against human HSP70 were purchased (catalog MA3-006) from Affinity BioReagents, Golden, Colo., and diluted 1:5,000 in TBS solution. In later experiments, the more homologous polyclonal, antiwheat (Triticum aestivum) HSP70 (provided by Elizabeth Vierling, University of Arizona, Tucson) were used. Polyclonal antibodies raised against the carboxy-terminal end of a recombinant cytosolic HSP18.1 from pea (Pisum sativum) (DeRocher et al., 1991) and the preimmune serum from the same rabbit were also obtained from Vierling. Both were diluted 1:1,000 in blocking solution. One set of blots was also incubated in the preimmune serum to check cross reactivity. Antibody binding was detected using alkaline phosphatase (AP) conjugated secondary antibodies (Sigma-Aldrich Co., St. Louis, Mo.). After exposure to the antibodies, the blots were washed three times with TBS with a 10min period between washes. The blots were developed using an alkaline phosphatase substrate kit (Bio-Rad). Molecular weights of the resulting bands were estimated by comparison with calibrated standard markers (Bio-Rad).

For separation of proteins by differences in isoelectric point (pI), $350 \mathrm{mg}$ protein was loaded onto a cylindrical $4 \%(\mathrm{w} / \mathrm{v})$ acrylamide gel (1.5 $\mathrm{mm}$ diameter, $100 \mathrm{~mm}$ in length) with a $\mathrm{pH}$ range of 4.2 to 7.5 and run under nonequilibrium condition $(400 \mathrm{~V}, 3.5 \mathrm{~h})$, according to O'Farrell et al. (1977). This was followed by SDS-PAGE in the second dimension after equilibrium of the cylindrical gels in SDS buffer and overlaid on top of the SDS slab gel. Proteins separated on twodimensional gels were stained with Coomassie Brilliant Blue R-250 in 10\% (v/ v) acetic acid and $40 \%(\mathrm{v} / \mathrm{v})$ methanol.

\section{Results}

HSP CONTENT IN FIVE CULTIVARS OF SUN AND SHADE APPLES. 'Fuji', 'Jonagold', 'Criterion', 'Gala', and 'Delicious' apples growing exposed to direct sunlight (sun) or growing shaded within the tree canopy (shade), were harvested 13 Aug. 1997. Peel samples were analyzed for HSP content using anti- bodies raised against human HSP70 and pea cytosolic HSP18.1. Due to high degree of conservation in amino acid sequence in HSP70, antibodies raised against the human HSP70 were immunoreactive with several proteins extracted from apple peel. Up to four proteins with estimated molecular weights of 70, 71.7, 74.4, and $76.7 \mathrm{ku}$ were recognized by the antibodies depending on the cultivar and location in the canopy (Fig. 1). In both sun and shade apples, two HSP70-related proteins (71.7 and $76.7 \mathrm{ku}$ ) were present in all cultivars, with the $71.7 \mathrm{ku}$ protein being the predominant one. One or two additional HSP70-related proteins (70 and $74.4 \mathrm{ku}$ ) were present in sun apples of all cultivars except 'Fuji', but the $70 \mathrm{ku}$ HSP was more prominent.

The pea HSP18.1 antibody recognized three related smHSPs with estimated molecular weights of 20.9, 22.0, and $22.5 \mathrm{ku}$ (Fig. 1). Based on relative intensity of the immunoreactions, all apple cultivars tested had greater amounts of HSP70 and smHSPs (as detected by the pea HSP18.1 antibodies) in the peel of sun apples than in shade apples. 'Fuji' sun apples had less HSP70 and smHSPs than sun fruit of the other four cultivars; the others each contained approximately equal amounts of HSPs. While two constitutively expressed HSP70 proteins were visible in shade tissue, the smHSPs were comparably low or undetectable in shade fruit.

CHANGES IN HSPS IN SUN APPLES IN RELATION TO FRUIT MATURITY. 'Fuji', 'Jonagold', and 'Gala' sun apples were sampled biweekly for HSP70 and smHSP analyses between 1 July and 21 Oct. 1997. Only smHSP data are presented (Fig. 2), as HSP70s did not show much variation. These three cultivars differ substantially in their time of maturity, as 'Gala', 'Jonagold', and 'Fuji' were picked commercially in 1997 in late August, late September, and late October, respectively. During July, as the maximum air temperature steadily rose, the smHSPs progressively increased (Fig. 2).

Fig. 2. (A) Maximum daily air temperatures recorded at the TFREC between 24 June and 28 Oct. 1997, and (B) smHSP content in the peel of 'Fuji', 'Jonagold', and 'Gala' sun apples sampled initially during the first week of July, and then harvested together every other week until 21 Oct. Drop lines in A indicate sampling dates. The western blot of total protein $(35 \mu \mathrm{g} / \mathrm{lane})$ was probed with antibodies against pea HSP18.1. Numbers with arrows indicate approximate molecular weights in unified atomic mass units $(\mathrm{u})$.

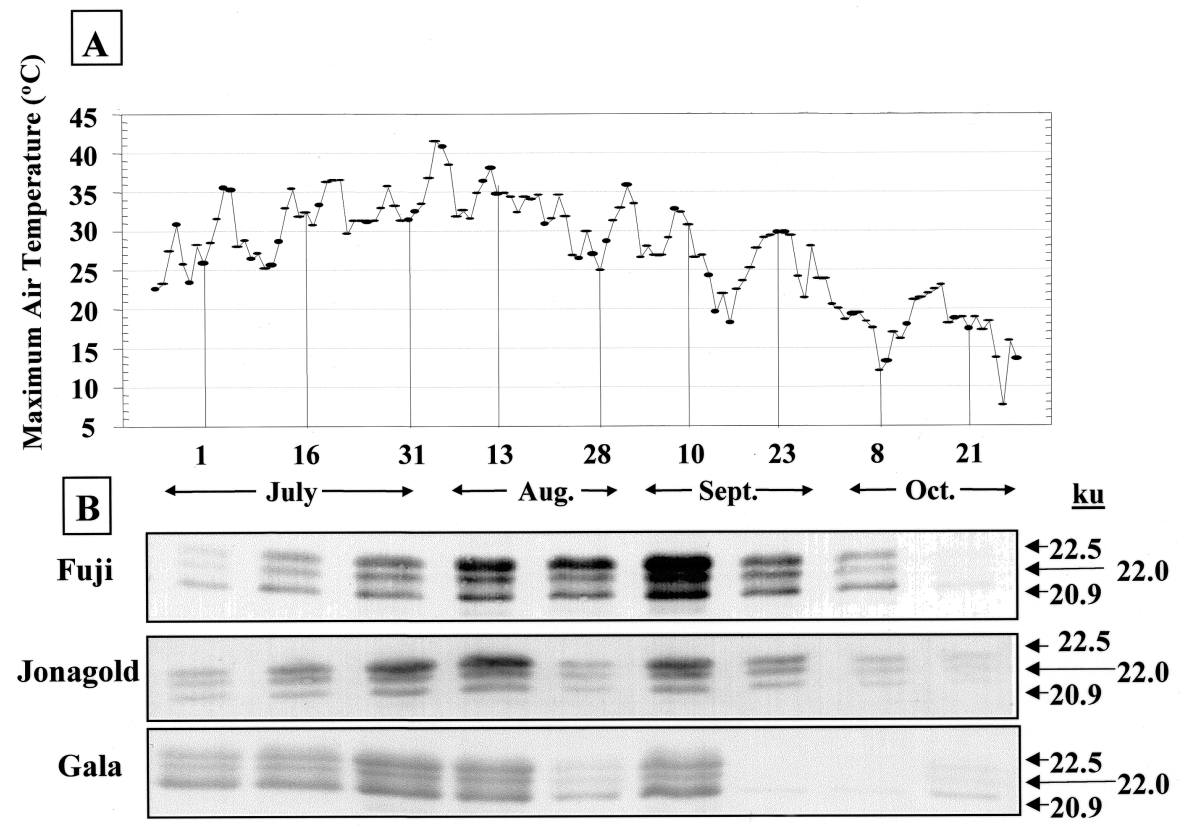


$\underline{\mathrm{ku}}$

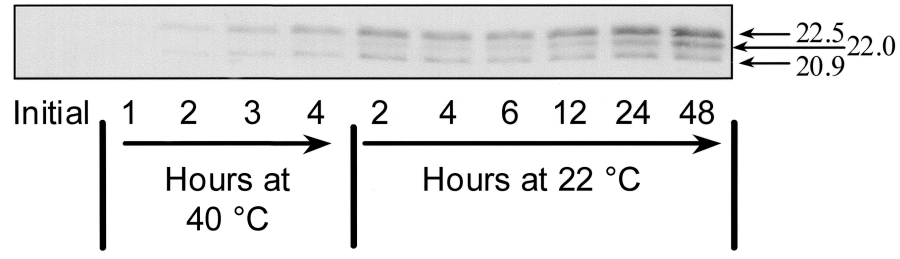

Fig. 3. SmHSP content in the peel of 'Fuji' shade apples exposed to $40{ }^{\circ} \mathrm{C}$ for 4 $\mathrm{h}$ and then held at $22^{\circ} \mathrm{C}$ for up to $48 \mathrm{~h}$. Fruit were harvested 7 Oct. 1997. Control (Initial) fruit received no heat treatment. The western blots of total protein (35 $\mu \mathrm{g} / \mathrm{lane})$ were probed with antibodies against pea HSP18.1. Numbers with arrows indicate approximate molecular weights in unified atomic mass units (u).

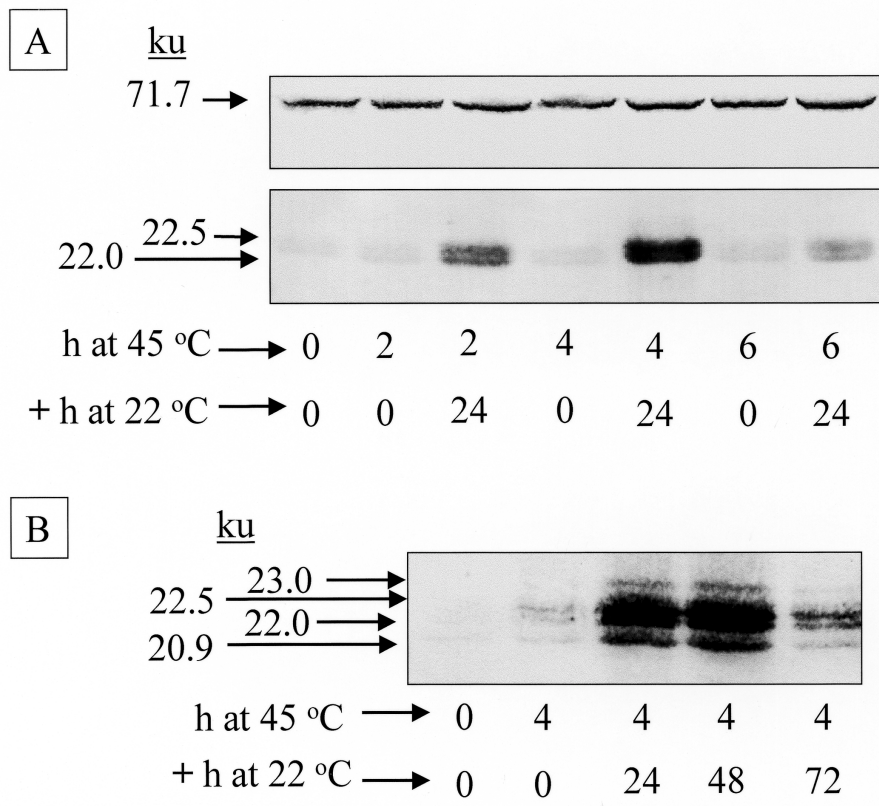

Fig. 4. (A) Effect of varying length (2 to $6 \mathrm{~h}$ ) of heat treatment at $45^{\circ} \mathrm{C}$ on accumulation of HSP70s and smHSPs in 'Fuji' shade apple peel and (B) effect of varying length of time at $22^{\circ} \mathrm{C}$ after heating apples at $45^{\circ} \mathrm{C}$ for $4 \mathrm{~h}$. All fruit were harvested 2 Sept. 1999. The western blots of total protein $(35 \mu \mathrm{g} / \mathrm{lane})$ were probed with antibodies against wheat HSP70 and pea HSP18.1. Numbers with arrows indicate approximate molecular weights in unified atomic mass units (u).

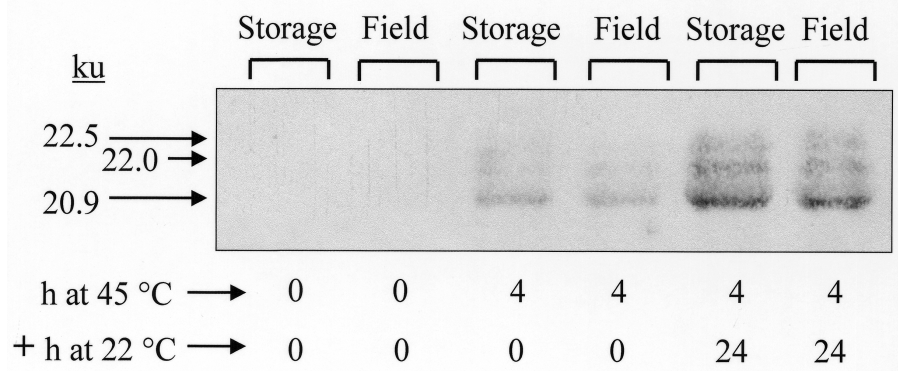

Fig. 5. Induction of smHSPs in heat-treated 'Fuji' sun apples either harvested at commercial maturity and stored at $4{ }^{\circ} \mathrm{C}$ for $60 \mathrm{~d}$ (storage) or harvested from the field $60 \mathrm{~d}$ after commercial maturity (field). Control fruit (i.e., $0 \mathrm{~h}$ at $45^{\circ} \mathrm{C}$ and $0 \mathrm{~h}$ at $22^{\circ} \mathrm{C}$ ) were harvested or taken from cold storage on $22 \mathrm{Dec} .1999(60 \mathrm{~d}$ after commercial maturity) (see lanes 1 and 2). Heated fruit were at $45^{\circ} \mathrm{C}$ for 4 $\mathrm{h}$, and either extracted immediately or held at $22^{\circ} \mathrm{C}$ for $24 \mathrm{~h}$ before extraction of HSPs. The western blots of total protein $(35 \mu \mathrm{g} / \mathrm{lane})$ were probed with antibodies against pea HSP18.1. Numbers with arrows indicate approximate molecular weights in unified atomic mass units (u).
The highest levels of smHSPs were detected in samples collected 31 July, 13 Aug., and 10 Sept. Each sampling date was during or immediately after periods of high temperature. The 28 Aug. sampling was taken during a period of cool weather. The effect of differing maturity dates for the cultivars is evident in that smHSPs in 'Gala' disappeared first, and smHSPs in 'Fuji' disappeared last (Fig. 2).

'Gala', 'Fuji', 'Delicious', 'Jonagold', and 'Criterion' apples were harvested 22 Dec. 1999, 60 to $120 \mathrm{~d}$ after commercial maturity, after being exposed to temperatures as low as $-4^{\circ} \mathrm{C}$ in the field before harvest. During the 48 -h period preceding harvest of the apples, maximum air temperature was $7{ }^{\circ} \mathrm{C}$ and the minimum air temperature was $-2^{\circ} \mathrm{C}$. A $71.7 \mathrm{ku}$ polypeptide was detected at similar levels in both the peel $(\mathrm{P})$ and cortex $(\mathrm{C})$ of all five cultivars studied using the polyclonal antiwheat HSP70 (data not presented). In contrast, no smHSPs were detected using the antipea HSP18.1 in either the peel or cortex of the same samples.

ChaRaCterization OF HEAT-INDUCED ACCUMUlation AND LOSS OF HSPs. 'Fuji' shade apples exposed to a $40{ }^{\circ} \mathrm{C}$ heat treatment began to produce detectable amounts of smHSPs $2 \mathrm{~h}$ into the treatment (Fig. 3). A $22.5 \mathrm{ku}$ protein band was detected first and most intensely, followed by the 20.9 and then $22.0 \mathrm{ku}$ proteins. All three proteins were detected at the end of the 4-h heat treatment but the $22 \mathrm{ku}$ protein did not become readily detectable until 6 to $12 \mathrm{~h}$ after the $4 \mathrm{~h}$ treatment at $40{ }^{\circ} \mathrm{C}$. The smHSPs continued to accumulate for $48 \mathrm{~h}$ after the apples were returned to $22{ }^{\circ} \mathrm{C}$.

'Fuji' shade apples harvested 2 Sept. 1999 were heated at 45 ${ }^{\circ} \mathrm{C}$ for 2,4 , or $6 \mathrm{~h}$ and then held at $22{ }^{\circ} \mathrm{C}$ for 0 or $24 \mathrm{~h}$ before extracting HSPs from the peel (Fig. 4A). When probed with the antiwheat HSP70 antibodies, a $71.7 \mathrm{ku}$ protein was present in all treatments and did not increase after the heat treatment. The smHSPs noticeably increased $24 \mathrm{~h}$ following the 2 or $4 \mathrm{~h} 45^{\circ} \mathrm{C}$ heat treatment. Highest smHSP levels were found in samples 24 $\mathrm{h}$ after receiving the 4-h heat treatment. Increasing the heat treatment from 4 to $6 \mathrm{~h}$ at $45{ }^{\circ} \mathrm{C}$ resulted in lower smHSP accumulation (Fig. 4A).

'Fuji' shade apples harvested 2 Sept. 1999 were heated for 4 h at $45^{\circ} \mathrm{C}$, and then held at $22^{\circ} \mathrm{C}$ for 24,48 , or $72 \mathrm{~h}$ after the heat treatment (Fig. 4B). Accumulation of smHSPs was very high 24 and $48 \mathrm{~h}$ after the heat treatment (peaking at $48 \mathrm{~h}$ ) before declining substantially $72 \mathrm{~h}$ after the heat treatment. Accumulation of smHSPs was negligible after heat treatments at 35 or $50^{\circ} \mathrm{C}$ (data not presented). We observed no visible injury of apples treated at either 40 or $45^{\circ} \mathrm{C}$. Apples treated at $50^{\circ} \mathrm{C}$ showed no injury, but surface color was slightly duller. Apples treated at $55^{\circ} \mathrm{C}$ in the laboratory developed extensive browning during the 2-h heat treatment.

As noted earlier, no smHSPs were detected in 'Fuji' apples harvested 22 Dec. 1999. Heating these field apples or storage apples (removed from cold storage after $60 \mathrm{~d}$ ) for $4 \mathrm{~h}$ at $45^{\circ} \mathrm{C}$ caused detectable smHSP accumulation after the heat treatment, and the smHSP levels increased further after holding at $22{ }^{\circ} \mathrm{C}$ for 24 h (Fig. 5).

TWO-DIMENSIONAL SEPARATION OF SMHSPS IN 'FUJI' APPLES. To ascertain how many additional proteins accumulated in apples as a result of heating the apples, 'Fuji' apples were harvested 1 Oct. 1998 and peel protein profiles from control (nonheated) versus heat-stressed $\left(4 \mathrm{~h}\right.$ at $40^{\circ} \mathrm{C}$ plus $48 \mathrm{~h}$ at $22^{\circ} \mathrm{C}$ ) were compared by two-dimensional gel analysis. In contrast to some proteins whose accumulation was reduced upon heat stress, up to 17 proteins, many of which we believe to be smHSPs with estimated molecu- 


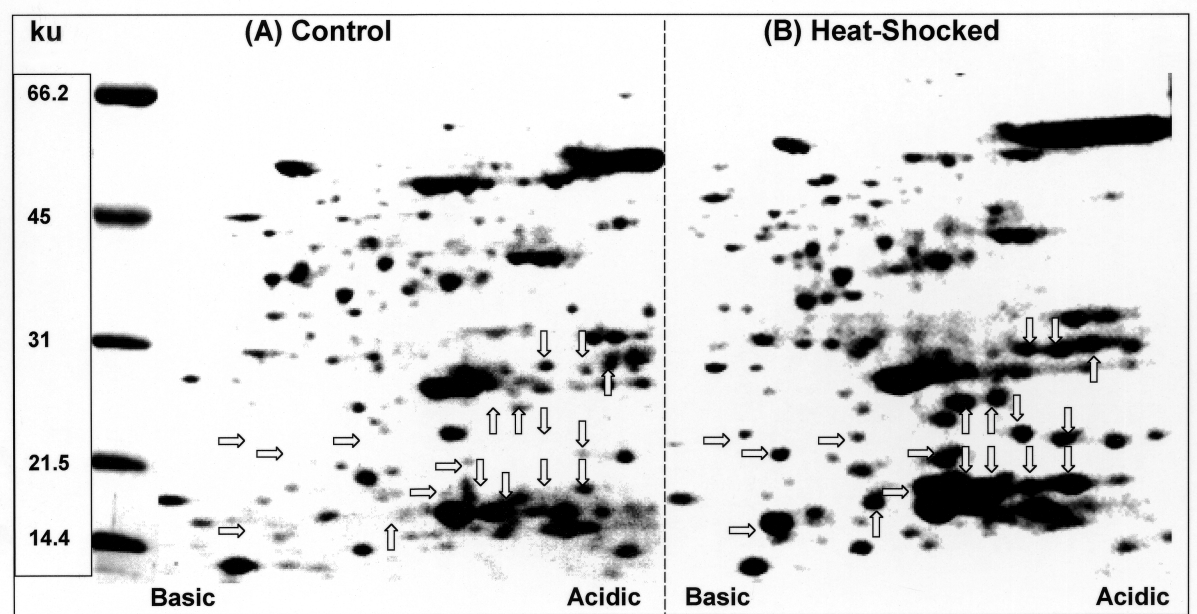

Fig. 6. Two-dimensional separation of 'Fuji' apple peel protein isolated from (A) control (nonheated) and (B) heat-shocked (heated at $40{ }^{\circ} \mathrm{C}$ for $4 \mathrm{~h}$ followed by $48 \mathrm{~h}$ at $22{ }^{\circ} \mathrm{C}$ ) apples. In A, numbers to the left indicate molecular weights in unified atomic mass units $(\mathrm{u})$. Proteins $(350 \mathrm{mg})$ were first separated in a cylindrical gel with a $\mathrm{pH}$ range of 4.2 to 7.5 under nonequilibrium conditions, followed by SDS-PAGE. SmHSPs accumulated in heat-stressed apples are indicated with arrows.

lar weights ranging from 15 to $29 \mathrm{ku}$, were found to accumulate in large amounts (Fig. 6). These include 15, 17, 18.1, 18.1, 18.2, $18.2,18.3,20,21.5,22,22.5,23,23.5,25,26,28$, and $29 \mathrm{ku}$ polypeptides. Most of these proteins were low or undetectable in nontreated apples, except for very small amounts of the 18.2, $18.3,26,28$, and $29 \mathrm{ku}$ polypeptides.

\section{Discussion}

We observed the presence of several HSP70 and HSP18.1related HSPs in the peel of sun exposed apples from the five cultivars tested (Fig. 1). The level of HSPs in shade apples was considerably lower. These five apple cultivars were chosen because of their different maturation dates and anecdotal reports of differences in sunburn susceptibility. 'Fuji', 'Jonagold', and 'Criterion' are thought to be more susceptible to sunburn than are 'Gala' and 'Delicious'.

HSP70 is highly conserved within nature and several different forms of the protein have been identified, including constitutively expressed and heat-induced forms (Morrell et al., 1997; Parsell and Lindquist, 1993, Perdue et al., 1998). Our initial experiments were conducted with antihuman HSP70 antibodies. We later switched to antiwheat HSP70 antibodies (from Vierling) as we reasoned that wheat antibodies would be more homologous to apple HSPs. Vierling (1991) noted the high degree of similarity in amino acid sequence between HSP70 proteins from seven plant species and human HSP70 protein. In our experiments, we found that the HSP70 class of proteins was detected with either human or wheat antibodies in all apple cultivars studied regardless of heat treatment or location of fruit in the canopy suggesting that one or more of the HSP70 bands was constitutive. However, the human HSP70 antibodies (Fig. 1) cross-reacted with more proteins than the wheat HSP70 antibodies (Fig. 4). The human HSP70 antibodies always detected at least two proteins in apples, and one or two additional HSP70-related proteins in fruit exposed to sunlight or higher temperature. We suggest that multiple members of the HSP70 family exist in apples. Two of them (71.7 and $76.7 \mathrm{ku}$ ) appear to be expressed constitutively in apple peel, as the $71.7 \mathrm{ku}$ protein was always present in our samples, and frequently showed no increase when apples were heated. One or two other HSP 70 family members ( 70 and sometimes $74.4 \mathrm{ku}$ ) induced by heat or exposure to sun were detected in apples with the human HSP70 antibodies, but not by the wheat HSP70 antibodies. Perdue et al. (1998) used five antibodies to identify a heat shock cognate protein (HSC70) that was constitutively expressed, and another HSP70 protein that was heat-induced in cherries.

With the wheat HSP70 antibodies, only the $71.7 \mathrm{ku}$ HSP was detected at high levels in apples left on the trees for 60 to $120 \mathrm{~d}$ after commercial maturity. The wheat antibodies detected no increase in HSP70 after heat treatments in the laboratory. This difference is interesting, as both human and plant HSP70 antibodies are capable of recognizing the constitutively expressed $71.7 \mathrm{ku}$ protein in apples, but only the human HSP70 antibodies can recognize the heat-inducible HSP70 proteins in apples. These results suggest that during evolution, plants and humans evolved a family of HSP70 proteins, presumably through gene duplication and modification, retaining the same epitope. However, our results indicate that the heat-inducible HSP70s in apples are detected only by the human antibodies, and not by wheat antibodies even though they would seem to be more homologous to apples than the human antibodies.

Class I cytosolic smHSPs are part of a large gene family and share a conserved carboxyl-terminal sequence of $\approx 100$ amino acids (deJong et al., 1993; Plesofsky-Vig et al., 1992; Vierling, 1991). In pea, HSP18.1 antibodies identified five related proteins, all thought to be Class I smHSPs (DeRocher et al., 1991). In apple, these antibodies recognized three to four proteins, and we assume that these immunoreactive smHSPs represent members of the cytosolic smHSPs, as the preimmune serum obtained from the same rabbit did not cross-react with proteins similar in mass to the smHSPs (data not presented).

Ferguson et al. (1998) studied expression of HSP70 and smHSP genes in 'Braeburn' apple fruit cortex and found that mRNA for HSP70 and smHSPs increased in flesh tissue at temperatures above $\approx 34{ }^{\circ} \mathrm{C}$ and required at least a 50-min exposure to induce increases in the mRNA. Maximum levels of mRNA were not observed until up to $9 \mathrm{~h}$ after the highest flesh temperatures were experienced. In flesh taken from the shade side of the fruit, mRNA for HSPs was much lower. In contrast to Ferguson et al. (1998), our study focused on protein accumulation using antibodies rather than mRNA accumulation using gene probes. Also, they used apple cortex ( $\geq 5 \mathrm{~mm}$ below the fruit skin) tissue rather than apple peel (epidermal and subepidermal tissue up to $\approx 1 \mathrm{~mm}$ from the surface), the tissue most exposed to higher temperatures and ultraviolet light in sun-exposed apples.

Woolf et al. (2000) reported that two smHSP peptides (Class I cytosolic) were detected with antipea HSP18.1 in avocado (Persea americana Mill.) flesh tissue harvested from sun-exposed fruit. These peptides were not detected in shade fruit or in nonexposed portions of sun fruit. Another antibody (Class II cytosolic) from pea (HSP17.6) cross-reacted with a smHSP in both sun and shade fruit, suggesting that it may be constitutive.

Using pea HSP18.1 antibodies, we found smHSPs in 'Fuji' shade peel were detectable after heating for $2 \mathrm{~h}$ at 40 or $45^{\circ} \mathrm{C}$ and observed no decline in apple peel smHSPs for at least $48 \mathrm{~h}$ after 
induction (Figs. 3 and 4). The 2-h lag time before detection of smHSP accumulation is consistent with Ferguson et al. (1998) who reported that at least $50 \mathrm{~min}$ of heat treatment is needed to induce mRNA for HSPs. In our studies, the level of smHSPs declined sharply between 48 and $72 \mathrm{~h}$ (Fig. 4B) when fruit were held at $22{ }^{\circ} \mathrm{C}$ after the heat treatment. These results indicate that, under our conditions, accumulation of smHSPs continues for $\approx 2$ $\mathrm{d}$ after the initial heat shock and that they have a low apparent rate of turnover at $22{ }^{\circ} \mathrm{C}$.

In pea, HSP18.1 protein has a half life of $38 \mathrm{~h}$, and when leaves were exposed to $40{ }^{\circ} \mathrm{C}$, HSP18.1 remained high for up to $3 \mathrm{~d}$ (DeRocher et al., 1991). However, HSP18.1 mRNA levels began to decline 6 to $8 \mathrm{~h}$ before the amount of HSP18.1-immunodetected protein reached maximum levels. While HSP18.1 mRNA in pea dropped quickly after returning the tissue to $22{ }^{\circ} \mathrm{C}$ (DeRocher et al., 1991), apple smHSP mRNA in the field fluctuated diurnally but remained high until at least 8 AM the next morning (Ferguson et al., 1998). Ferguson et al. (1998) suggested that low night temperatures (flesh temperature of $\approx 15^{\circ} \mathrm{C}$ ) may retard the loss of HSP mRNA. Our results indicate that because of the long half life of HSPs, even if diurnal HSP mRNA levels fluctuate widely, protein levels would be expected to change less rapidly and more in response to net daily mRNA levels. Moreover, sun-exposed apples in the field frequently experience several consecutive days in which fruit surface temperature exceeds $40^{\circ} \mathrm{C}$. This probably causes mRNA for smHSPs to be induced daily to keep smHSP levels high in the sun-exposed side of apples. Even in shade fruit, though maximum fruit surface temperatures were lower than in sun fruit, diurnal fluctuation in air temperature may have at times been adequate to induce small amounts of smHSPs (Fig. 1).

Peel samples taken between 1 July and 21 Oct. from 'Fuji', 'Jonagold', and 'Gala' sun apples revealed that synthesis of the $18.1 \mathrm{ku}-$-related smHSPs can fluctuate in response to environmental changes and maturity (Fig. 2). Apple samples were collected before the hottest part of the day and therefore the temperatures experienced by the fruit during the days immediately preceding the sampling date likely had the greatest impact on observed HSP levels. This is supported by the fact that high temperatures can influence HSP levels for at least $48 \mathrm{~h}$ (Figs. 3 and 4B).

The smHSPs in apples, identified by the pea HSP18.1 antibody, were usually at their highest levels on 31 July, 13 Aug., and 10 Sept., generally corresponding to periods of highest air temperatures. Air temperature alone is not the best index for predicting smHSP content at each sampling date, as fruit surface (peel) temperature is influenced by several factors (e.g., solar irradiance, clouds, and wind velocity) besides air temperature. We have observed fruit surface temperatures as much as $16^{\circ} \mathrm{C}$ above ambient temperature; that is similar to the $15^{\circ} \mathrm{C}$ increase in fruit surface temperature reported by Ferguson et al. (1998). It would have been ideal to have thermocouples in each fruit, but the volume of fruit sampled throughout the season made such direct peel temperature measurements problematic. Other factors such as maturity may also influence the degree of smHSP synthesis in apple; smHSPs started disappearing first from 'Gala', which matured first, and started disappearing last from 'Fuji', which matured last. Hernandez and Vierling (1993) found what appears to be a developmental component regulating smHSP expression in legume seeds and seed pods.

The relationship between maturity date and time of disappearance of smHSPs from different apple cultivars (Fig. 2) supports the hypothesis that some type of developmental regulation exists. However, most of our observations point to environmental fac- tors (particularly high temperature) as being the primary determinant of smHSP content in apple peel. In the laboratory, smHSPs appeared only when apple peel had been heated to $\approx 40{ }^{\circ} \mathrm{C}$ or higher, and could be induced by heating apples even $60 \mathrm{~d}$ after commercial maturity (Fig. 5). The smHSPs identified herein do not appear to be induced by low temperatures, as no smHSPs were detected in fruit from cold storage or from the field $60 \mathrm{~d}$ after maturity. The late maturity and low temperatures in the field had obviously not destroyed the smHSP-synthesizing machinery of these postclimacteric fruit; the fruit could still produce smHSPs in response to heat shock (Fig. 5). In the field, smHSPs were much higher in peel of attached fruit exposed to direct sunlight than in peel from shaded fruit. Sun-exposed fruit were warmed by solar energy, with the exposed side being as much as $16^{\circ} \mathrm{C}$ above ambient temperature (data not presented). Air temperature exceeded $35^{\circ} \mathrm{C}$ on several days during the season (Fig. 2A), so that fruit surface temperature would have reached $45^{\circ} \mathrm{C}$ or higher several times during the season.

SmHSPs are expressed in legume seeds, seedpods, and flowers at temperatures well below the $\approx 30{ }^{\circ} \mathrm{C}$ required for smHSP expression in pea leaves (DeRocher et al., 1991; Hernandez and Vierling, 1993). It has been suggested that smHSPs may be important for reproductive success and that reproductive tissue may have inherently higher smHSP levels or induce smHSPs synthesis at lower temperatures (Hernandez and Vierling, 1993). Apples are pome fruit derived from fused floral (perianth) tissue, which together with carpel tissue become fleshy and edible. In our experiments, smHSPs were low or undetectable in shade apples even though maximum air temperatures were all above $30^{\circ} \mathrm{C}$ for $20 \mathrm{~d}$ leading up to the 13 Aug. sampling date. Shade apples likely reached temperatures near air temperature (Brooks and Fisher, 1926; our unpublished data). Thus, expression of smHSPs in the peel of apple pome fruit requires higher temperatures $\left(>30^{\circ} \mathrm{C}\right)$ than pea seedpods or flowers $\left(<30^{\circ} \mathrm{C}\right)$.

The large quantity and number of different proteins that accumulated in heat-stressed 'Fuji' apple peel are striking (Fig. $6)$. We found distinct increases in 17 protein bands, many of which we believe are smHSPs, after a 4-h heat stress at $40{ }^{\circ} \mathrm{C}$ followed by $48 \mathrm{~h}$ at $22^{\circ} \mathrm{C}$. Presumably, these diverse smHSPs are distributed in different cellular compartments (cytosol, endoplasmic reticulum membrane, mitochondria, and chloroplasts). Because we have identified only four smHSPs so far (presumably all class I, cytosolic HSPs) using antibody raised against pea HSP18.1, several additional smHSPs may be present in apple peel. Further identification of these smHSPs in apple peel, determination of their localization, and their response to different light and temperature conditions are needed. A systematic study of the induction and accumulation of different classes of smHSPs in various apple tree parts and organelles is in progress in our laboratory.

\section{Literature Cited}

Bradford, M.M. 1976. A rapid and sensitive method for the quantitation of microgram quantities of protein utilizing the principle of protein-dye binding. Anal. Biochem. 72:248-254.

Brooks, C. and D.F. Fisher. 1926. Some high-temperature effects in apples: Contrasts in the two sides of an apple. J. Agr. Res. 32:1-16.

deJong, W.W., J.A.M. Leunissen, and C.E.M. Voorter. 1993. Evolution of the $\alpha$-crystallin/small heat-shock protein family. Mol. Biol. Evol. 10:103-126.

DeRocher, A.E., K.W. Helm, L.M. Lauzon, and E. Vierling. 1991. Expression of a conserved family of cytoplasmic low molecular weight heatshock protein during heat stress and recovery. Plant Physiol. 96:10381047. 
Ferguson, I.B., W. Snelgar, M. Lay-Yee, C.B. Watkins, and J.H. Bowen. 1998. Expression of heat shock protein genes in apple fruit in the field. Austral. J. Plant Physiol. 25:155-163.

Gatenby, A.A. and P.V. Viitanen. 1994. Structural and functional aspects of chaperonin-mediated protein folding. Annu. Rev. Plant Physiol. Plant Mol. Biol. 45:469-491.

Härndahl, U., R.B. Hall, K.W. Osteryoung, E. Vierling, J.F. Boreman, and C. Sundby. 1999. The chloroplast small heat shock protein undergoes oxidation-dependent conformational changes and may protect plants from oxidative stress. Cell Stress \& Chaperones 4:129-138.

Hartl, F.U. 1996. Molecular chaperones in cellular protein folding. Nature 381:571-580.

Hendrick J.P and F.U. Hartl. 1995. The role of molecular chaperones in protein folding. FASEB J. 9:1559-1569.

Hernandez, L.D. and E. Vierling. 1993. Expression of low molecular weight heat-shock proteins under field conditions. Plant Physiol. 101:1209-1216

Jakob, U., M. Gaestel, K. Engel, and J. Buchner. 1993. Small heat shock proteins are molecular chaperones. J. Biol. Chem. 268:1517-1520.

Kochhar, S., J. Zhang, V.K. Kochhar, M.A. Ritenour, M.S.B. Ku, and L.E. Schrader. 2000. Heat shock proteins in apple fruit. Plant Physiol. 123:S104 (abstr. 465).

Laemmli, U.K. 1970. Cleavage of structural proteins during the assembly of the head of bacteriophage T4. Nature 227:680-685.

Lee, G.J., N. Pokala, and E. Vierling. 1995. Structure and in vitro molecular chaperone activity of cytosolic small heat shock proteins from pea. J. Biol. Chem. 270:10432-10438.

Lee, G.J., A.M. Roseman, H.R. Saibil, and E. Vierling. 1997. A small heat shock protein stably binds heat-denatured model substrates and can maintain a substrate in a folding-component state. EMBO J. 16:659-671.
Lindquist, S. and E.A. Craig. 1988. The heat-shock proteins. Annu. Rev. Genet. 22:631-677.

Morrell, A.M., R.L. Wample, G.I. Mink, and M.S.B. Ku. 1997. Heat shock protein expression in leaves of 'Cabernet Sauvignon'. Amer. J. Enol. Viticult. 48:459-464.

O'Farrell, P.Z., H.M. Goodman, and P.H. O'Farrell. 1977. High resolution of two-dimensional electrophoresis of basic as well as acidic proteins. Cell 12:1133-1142.

Parsell, D.A. and S. Lindquist. 1993. The function of heat-shock proteins in stress tolerance: Degradation and reactivation of damaged proteins. Annu. Rev. Genet. 27:437-496.

Perdue, D.O., E.J. Mitcham, and L.G. Neven. 1998. Transient expression of HSC70 in cherry fruit subjected to heat shock. J. Agr. Food Chem. 46:4447-4450.

Plesofsky-Vig, N., J. Vig, and R. Brambl. 1992. Phylogeny of the $\alpha-$ crystallin-related heat-shock proteins. J. Mol. Evol. 35:537-545.

Ritenour, M., L. Schrader, and M. Ku. 1998. The presence of heat-shock proteins in sun-exposed and heat-treated apple fruit. HortScience 33:452 (abstr.)

Van Etten, J.L., S.N. Freer, and B.K. McCune. 1979. Presence of a major (storage?) protein in dormant spores of the fungus Botryodiplodia theobromae. J. Bacteriol. 138:650-652.

Vierling, E. 1991. The roles of heat shock proteins in plants. Annu. Rev. Plant Physiol. Plant Mol. Biol. 42:579-620.

Waters, E.R., G.J. Lee, and E. Vierling. 1996. Evolution, structure and function of the small heat shock proteins in plants. J. Expt. Bot. 47:325338.

Woolf, A.B., A. Wexler, D. Prusky, E. Kobiler, and S. Lurie. 2000. Direct sunlight influences postharvest temperature responses and ripening of five avocado cultivars. J. Amer. Soc. Hort. Sci. 125:370-376. 